\title{
“When All Muslims Unite ...": Islamism, Identification, and Western Fears of Terrorism in Africa
}

\section{Kurt Shillinger *}

The rapidly successful expulsion from Somalia in early January 2007 of Islamist faction the Union of Islamic Courts (UIC) provides a tempting tactical model for countering terrorism in far-flung locations. Yet, in some respects, the success of the model was surprising. The Union of Islamic Courts took Mogadishu in early June 2006, and steadily expanded its control across the southern portion of Somalia, meeting little resistance. The UIC seemed so secure in its control of southern Somalia that, until the eve of its defeat, it boasted openly of ambitions of creating a united Islamic "Greater Somalia," including all of breakaway Somaliland, Djibouti, and parts of Ethiopia. The operation was carried out by Ethiopian ground and air forces on behalf of the Somali Transitional Federal Government (TFG), which was constituted through regional negotiations in Kenya more than two years ago but had never gained more than a tenuous hold in the provincial town of Baidoa, far from the capital of Mogadishu. The Ethiopians acted with the tacit approval of Washington, and received minimal participation from U.S. Special Forces advisers.

Faced with overwhelming firepower from the Ethiopians, the Islamist faction fell like a house of cards, its leaders and militias melting away under cover of darkness rather than waging a fight. Their displacement and the subsequent installment of the TFG in Mogadishu was followed by U.S. air strikes in Mogadishu and along the Kenyan border against alleged Al Qaeda operatives allied to the deposed Islamists. Even before the Pentagon indicated whether or not those air strikes had hit their intended targets-Abu Talha al-Sudani, a Sudanese national suspected by the U.S. of being a long-time associate of Osama bin Laden based in East Africa, and Fazul Abdullah Mohammed and Saleh Ali Saleh Nabhan, two other alleged Al Qaeda operatives suspected in the 1998 U.S. Embassy bombings in East Africa-U.S. military strategists were already indicating that the combined use of selective strikes and "surrogate forces" like the Ethiopians provided a "blueprint ... they hoped to use more frequently in counterterrorism missions around the globe."

Targeting suspected terrorists using military methods, however, is at best a dubious enterprise. Certainly, the killing and/or arrest of key known associates of Osama bin Laden has undermined and isolated the group's core leadership. The death of Abu Musab al-Zarqawi, the supposed leader of Al Qaeda in Iraq, however, did little to defuse the violent insurgency there. While the impact of the U.S. air strikes on possible terror-related activity in Somalia may always be uncertain, the effects of those attacks

\footnotetext{
* Kurt Shillinger is Africa Security and Terrorism Research Fellow at the South African Institute of International Affairs in Johannesburg.

1 Mark Mazzetti, “Pentagon Sees Move in Somalia as Blueprint,” New York Times (13 January 2007); available at www.nytimes.com/2007/01/13/world/africa/13proxy.html.
} 
on Muslim attitudes across Africa registered immediately. The more reactionary voices that emerged were to be expected. Iqbal Jasset, chairman of the Media Review Network, a Muslim advocacy group based in Pretoria, wrote in an op-ed:

That America is hell-bent on catapulting the globe into a head-on collision with Muslims who are defined as "terrorists" is a reality and widely known. What is lesser known and not sufficiently debated is the fact that the defining characteristic of these so-called "terrorists" is their individual and collective refusal to submit to U.S. dictates. What it means therefore is that maintaining client-states in power requires the elimination of their adversaries. ${ }^{2}$

More worrisome was the criticism coming from more moderate voices. Hussein Solomon, a measured Muslim academic at the University of Pretoria, warned in the wake of the air strikes that South Africa's participation in the proposed UN-backed African peacekeeping mission to Somalia, Igasom, would be a "bad bad move," adding, "There are some who might see this as South Africa joining the 'infidel' agenda."3

These remarks, while anecdotal, reflect two important factors. First, the robust U.S. military response in the wake of 9/11 and in the name of countering terrorism has both spread and deepened the perception among Muslims worldwide that the West is waging a war against Islam. Asked why some Muslims resort to terrorism, for example, Nassurulahe Intizane Dulá, the genteel provincial representative of the Mozambique Muslim Congress in the predominately Muslim northern province of Cabo Delgado, responded: "There is no other way to fight against the United States. The U.S. knows that when all Muslims unite, it will be dangerous for them."4

Second, Washington's support for the Ethiopian operation against the Islamic Courts and the subsequent air strikes have fundamentally altered Muslim perceptions about the nature of international intervention in Somalia. In the sixteen years since the collapse of the Siad Barre regime in Somalia, there have been almost as many international attempts to constitute a new central government. Those attempts all failed because, as the British anthropologist Ioan Lewis notes, they were externally engineered, involving "an idiosyncratic selection of participants, belonging to-but not actually representing-different clans." 5 Such efforts were more reflective of UN aspirations to install a government than of prevailing internal social and political dynamics within Somalia. The TFG can be similarly appraised. Cobbled together in exile through negotiations formulated by regional actors, it faced an internal reception so hostile that its leaders could not even enter Mogadishu. Time has not improved its standing with ordinary Somalis.

2 Iqbal Jassat, "Bush Goes on Africa Crusade,” The Citizen (17 January 2007).

3 Quoted in Peter Fabricius, “SA Troops Face ‘Black Hawk Down’ Perils,” Sunday Independent (14 January 2007).

4 Interview with Nassurulahe Intizane Dulá, Complexo Nautilus, Pemba, Mozambique, 4 January 2007.

5 Ioan M. Lewis, "UN 'Peace Process' Creates New Somali Warlord and Re-ignites Somali Wars,” 24 October 2000, available at www.somaliawatch.org/archiveoct00/001029201.htm. 
Now, however, following the forced displacement of an Islamist faction and air strikes by two foreign powers, the installation of the TFG can no longer simply be seen as an attempt by the regional and international communities to help lift Somalia out of anarchy. The project presently afoot—at least as many Muslims in Africa view it—is to wage war against Islamic governance. If the goal of stabilizing Somalia-the quintessential ungoverned space-is to remove a potential safe haven and logistical hub for transnational terror, the Ethiopian and U.S. intervention may in fact have deepened the affinity of African Muslims for those of their co-religionists who resort to terrorism as a tactic of jihad.

This essay argues that countering ideological support for terrorism in Africa requires a different approach. It begins by noting that Africa's many and diverse Muslim communities are historically peaceful and that, at least in sub-Saharan countries, Islam as an identity is more often subordinate to more localized ethnic customs and allegiances. There is, however, at least a potential for the latter to change. Islam is the fastest growing religion in Africa. The West's post-9/11 military adventures elsewhere in the Muslim world, chronicled through the Internet and twenty-four-hour global realtime media, have increasingly exposed and united African Muslims to the grievances of their brethren farther afield. Most African Muslims are poor, and many live under the grip of repressive and corrupt regimes. Interviews with Muslims in a broad range of rural and urban settings in Africa, and the growth of Islamic charities and political parties across the continent, suggest that these factors are encouraging a form of identity that is more defined by confessional affiliation. Where this "Islamic consciousness" is political—as opposed to being primarily social—it is a reaction both to the war on terror (the perception of a war against Islam) and local circumstances (the daily reality of social misery and political exclusion). Consequently, efforts to stem ideological support for terror-related activity in Africa must be based on preventing or repairing cleavages between states and their Muslim populations by strengthening state capacity and broadening national political systems to address the socio-economic needs and political aspirations of those communities.

\section{Islam, the Nation-State, and the West}

In his cogent analysis of extremism in Pakistan, Hassan Abbas notes that, "For decades, higher national interests have compelled American administrations to support highly repressive regimes in many Muslim countries.”6 This statement echoes the seminal texts of the influential Egyptian writer Sayyid Qutb, whose writings have been foundational to the Islamist ideology of Osama bin Laden and his associates. Qutb wrote: "The Americans and their allies in the Middle East reject an Islam that resists imperialism and oppression."7 The critical problem that emerges is the relationship between the United States and key governments in the Muslim world, and in concerned

6 Hassan Abbas, Pakistan's Drift Into Extremism (Delhi: Pentagon Press, 2005), 237.

7 Sayyid Qutb, quoted in Richard Bonney, Jihad: from Qu'ran to bin Laden (New York: Palgrave Macmillan: 2004), 398-99. 
regions more broadly—not the U.S. itself. Presumably, for Qutb, this would include Israel, but as Abbas and others have subsequently pointed out, it also has included at one time or another the House of Saud, the Shah of Iran, and Saddam Hussein in Iraq (to name only a few).

The U.S., however, was not the initial target of the Islamist movement. As Fawaz Gerges points out, Ayman al-Zawahiri, bin Laden's chief deputy, may regard the United States as the "leader of the criminals," but until the late 1990s he "was emphatic about the need to keep the fight focused on the near enemy" - the "apostate" regimes of the Muslim world. ${ }^{8}$

Islam and the nation-state have a long and troubled history. The consolidation of the latter marked the fragmentation of the former-or, as Mahmood Mamdani suggests, the advent of the nation-state marked the beginning of an unresolved conflict between two systems competing for global conquest. Mamdani charts this confrontation back to 1492, the year "the armies of King Ferdinand and Queen Isabella conquered the city-state of Granada, then seen as the last Muslim stronghold in western Christendom." In the contemporary period, Bassam Tibi notes, "nation-states have failed to meet the twin challenges of promoting economic growth and erecting institutions for political participation" in the Middle East and North Africa. "They have failed, in short, to combine economic prosperity with democracy." ${ }^{10}$ As a result,

The "primacy of the nation state as a universal political form of the current era" is not a construct acceptable to Islamic fundamentalists, and their revolt against the nationstate leads to a process of de-legitimization. To be sure, the legitimacy crisis of the nation-state in the World of Islam has not been brought on by religious fundamentalism. It is, rather, the other way around: the crisis of legitimacy derives from the failure of the nation-state to strike roots in an alien civilization, and fundamentalism, seeing its opportunity, is the political articulation of that crisis. ${ }^{11}$

This problem of the nation-state failing to adequately supplant the social and political order that Islamists seek to achieve through Islam is no less acute in sub-Saharan Africa-where few states are predominately Muslim-than in the Muslim world proper. As Holger Weiss observes, the growth in academic interest in the social welfare of African Muslim communities in recent years reflects two simultaneous conditions: "the few, if not non-existent possibilities of the states to provide for basic needs of their subjects, a situation that has become painfully evident in most African states," and "the rise of Islamism and the critique of the secular state, not only in Africa but throughout the Muslim world."12

8 Fawaz Gerges, The Far Enemy: Why Jihad Went Global (Cambridge: Cambridge University Press, 2005), 13.

9 Mahmood Mamdani, Good Muslim, Bad Muslim (Johannesburg: Jacana Press, 2004 ), 5.

10 Bassam Tibi, The Challenge of Fundamentalism (Berkeley: University of California Press, 2002), 8.

11 Idem.

12 Holger Weiss, ed., Social Welfare in Muslim Societies in Africa (Stockholm: Nordiska Afrikainstitutet, 2002), 5. 
Jared Diamond provides a concise description of the security mechanics of failed states, noting that those countries with "the worst problems of environmental stress, overpopulation, or both" also happen to be "the world's worst trouble spots": ${ }^{13}$

[C]ountries that are environmentally stressed, overpopulated, or both become at risk of getting politically stressed, and of their governments collapsing. When people are desperate, undernourished, and without hope, they blame their governments, which they see as responsible for or unable to solve their problems. They try to emigrate at any cost. They fight each other over land. They kill each other. They start civil wars. They figure that they have nothing to lose, so they become terrorists, or they support or tolerate terrorism. ${ }^{14}$

This is as true in Nigeria and South Africa, I would argue, as it is in Saudi Arabia or Afghanistan.

Diamond's point finds a compelling illustration in Somalia and its self-governed secessionist northern territory of Somaliland. While the south has festered anarchically since 1991 despite so many international attempts to impose a central government, Somaliland has quietly and persistently rebuilt itself from within. Although it has failed to win international recognition, it has a democratically elected government and legislature and enjoys the benefits of both reconstruction and stability. During the past decade, Somalia has been used at least three times as a staging ground for cross-border terrorist attacks against Western targets in neighboring states and as a suspected safe haven for Al Qaeda operatives. In the same period of time, Somaliland has not been completely immune to Islamism. But, as Lewis notes, "It is fortunately true that Somaliland has managed to preserve its secular system of modern democracy, despite the presence of fundamentalist undercurrents. I think its stability reflects general satisfaction with its democratic system and two chamber legislature.”15

\section{Terrorism and State Weakness in Africa: Three Country Briefs}

Across Africa, different dynamics play out in different contexts. Certain states are prone to terrorist attacks, but the continent as a whole is not. In other areas, the primary terror-related concerns are financial, economic, or people-centered, related to issues such as money laundering and smuggling; mutual commercial interaction between Islamists and locals, and safe haven and documentation abuse. In all cases, state weakness is a central factor. It is not that nomadic Touaregs in northern Mali are particularly sympathetic to the attempts of Algerian Islamists to sack Algiers. Rather, the inability of the government in Bamako to exert sufficient control over its vast and empty northern desert spaces to offer jobs, education, health care, and foodstuffs provides an

13 Jared Diamond, Collapse: How Societies Choose to Fail or Succeed (New York: Penguin Books, 2005), 516.

14 Idem.

15 Ioan M. Lewis, quoted in "Post Global: Somalia's Islamic Courts," an online interactive debate forum of The Washington Post (30 August, 2006); at www.washingtonpost.com/wpdyn/content/discussion/2006/08/14/DI2006081400488.html. 
opening for cross-border alliances of economic convenience. Islamists driven southward from Algeria, who finance their operations by smuggling goods like pasta and cigarettes, find a ready, desert-savvy labor force in northern Mali. The issue is less one of radicalization and recruitment than it is the simple articulation of local economy, a situation that applies, in varying ways, across the continent. Such local realities should have a strong influence on any efforts that are undertaken to attempt to counter ideological support for terrorism, since this case shows that ideological support is really not the issue. The following section will briefly consider three relationships between the state, Islamism, and terror-related activity in Africa.

\section{Morocco}

The westernmost Arab North African state features all of the characteristics that enable or encourage terrorism in Africa: political exclusion, economic desperation, political and physical proximity to the West, corruption, and religious division. Morocco is a constitutional monarchy, where almost all power is vested in the king. Its sovereign claims special religious legitimacy through direct lineage to the Prophet Muhammad. As one assessment concludes, "Morocco is as vulnerable to Islamist violence as most other countries in the Arab world, through the combination of economic fragility, social deprivation, corruption, a weak parliament, and a powerful monarchy that bases its legitimacy on Islamic tradition."16

The monarchy has ruled Morocco since independence in 1956. Relative to its regional counterparts, the country has solid economic indicators. GDP growth reached 5.2 percent in 2003, according to the World Bank World Development Indicators; inflation was low, at 1.2 percent, but formal unemployment hovered at 11 percent. But when Morocco's performance is measured against poverty indices, even this growth rate is insufficient. Some 19 percent of the adult population lives below the national poverty line, while 50 percent is illiterate. Gross national per capita income, at USD 1,310 , is below the regional average. Traditional revenue sources-remittances, agricultural exports, and tourism-were insufficient to balance the external account in 2005, and the same is projected to be true of 2006. Privatization has been slow and marked by cronyism.

The eruption of Islamist violence in Morocco in 2003-04 exposed the dangers of the monarchy's fragile political balance. King Mohammed VI claims that Morocco's violent Islamist threat originates from elsewhere, particularly Egypt and Algeria. In fact, the May 2003 Casablanca attacks were almost entirely an internal affair. Planning, logistics, and recruitment activities all took place in a Casablanca slum called Karian Toma, where policing is poor, and idle, jobless, uneducated young men are plentiful. As Jack Kalpakian notes, "There is consensus that the primary enabling factors that led to the availability of suicide bombers are poverty and illiteracy. Places like Karian Toma are underserved and suffer from the lack of economic opportunities.” Furthermore, he observes, Morocco's "proximity to Europe, the transmission of images from

16 Oxford Analytica, “Morocco: Kingdom Faces Threats from Militant Islamism,” 9 November 2004. 
Europe, and the 'European letters' sent by the Moroccans already there have made many Moroccans feel more impoverished than they really are.”17

The unification of religious and political authority in the person of the monarch carries inherent vulnerabilities. The king can use religious justifications for demonizing his political opponents, while internal critics may argue that poor governance or unpopular political reforms are "un-Islamic." The planners of the Casablanca attacks appropriated the jihadist rhetoric of $\mathrm{Al}$ Qaeda against a state they regarded as apostate. There is almost no way for external partners of the regime to walk a middle path through this conundrum, particularly in the presence of a violent extremist opposition. Although only one Islamist group among several in Morocco espouses violence, the monarchy's Western partners showed little ability to make the distinction. In much the same way that the monarchy used the threat of communism to secure Western support during the Cold War, it is now doing the same with Islamism to present itself to the West as a key ally in the war on terror.

The regime responded to the attacks with a series of quick reforms, including guarantees of greater gender equality and marginally improved political liberalization. These proved counter-productive, to the extent that they exacerbated the Islamists' critique that the monarchy was governing in a manner contrary to Islam. Any substantial gains in political tolerance following the attacks have since been reversed. Only one moderate Islamist group has been legalized, and mass arrests against Islamists have become commonplace. The monopoly on power invested in the monarchy, meanwhile, has rendered the parliament nearly impotent, and this has in turn left secular political parties largely unable to exercise any measure of checks and balances. Popular political and economic frustration consequently has few effective release valves.

\section{Nigeria}

Poverty, the unequal distribution of political power and economic resources (in this case, oil revenues) between Christians and Muslims, geographical location, and perpetual corruption and misrule combine to render Nigeria susceptible to both internal and external Islamist ferment. Osama bin Laden has noted with specific encouragement the spread of sharia law and radicalized Islam in the north, which juts upward into the desert Sahel region, which is traversed by numerous traditional trade and smuggling routes. In a June 2006 column in Sada al-Jihad (Echo of Jihad), a Saudi online magazine held to be affiliated to Al Qaeda, a writer calling himself Abu Azzam al-Ansari finds specific exploitable vulnerabilities in the mystical Sufi practices of Muslims in Nigeria: "Many holy warriors in other countries have learned that working with the Sufis is easier than working with any other sect, such as the Shi'ites or the Communists." 18 Peter Pham expands on this notion by observing that "the Sufi brotherhoods among [northern Nigeria’s] largely Muslim Hausa and Fulani peoples have long-

17 Jack Kalpakian, "Building a Human Bomb: The Case of the 16 May 2003 Attacks in Casablanca,” Studies in Conflict and Terrorism 28 (2005): 113-27.

18 Abu Azzam al-Ansari, quoted in Peter Pham, “Al Qaeda Moves to Africa,” World Defense Review (27 July 2006). 
standing ties with the Middle East and, following the colonial interlude, proved receptive to the ministrations of Saudi-educated imams who looked down upon more moderate expressions of Islam." 19

Richly endowed with natural resources, Africa's most populous country nonetheless ranks number fifty-four out of sixty on the Foreign Policy Failed States Index, which cites uneven development, poor security provision, and factionalism among elites as key indicators of instability. Poverty is paradoxically acute where oil reserves and mineral deposits are greatest. The eighth-largest oil producer in the world, Nigeria ranks 158 in the UN Human Development Index. Despite GDP annual growth rates topping 10 percent in recent years, 90 percent of the population live on less than USD 2 a day. Infant mortality is the second highest in the world after India, and the UNDP estimates it will take Nigeria forty years to reach the basic health targets outlined in the Millennium Development Goals. The country's oil wealth, meanwhile, suppresses foreign aid flows, and has made lenders less inclined to offer debt relief. Nigeria's annual debt service bill exceeds USD 3 billion.

The root cause of the country's political and economic instability resides in its flawed federal system, which was supposed to institutionalize power sharing between ethnic and tribal groups, ensure common control of natural resources, and provide a structure for the equal distribution of revenues. Instead, it has led to sectarian abuses of state institutions, endemic corruption, and political and ethnic alienation. Federalism was supposed "to balance the apportionment of political positions, jobs and other government benefits evenly among Nigeria's many peoples but is distorted by a second principle, that of indigeneity, which makes the right to such benefits dependent upon where an individual's parents and grandparents were born."20 Internal movement consequently takes on a character of internal displacement, the penalty for which is discrimination and ostracism, which fuels political resentment and sectarian politics. One manifestation of this is the deepening of sharia law in the twelve predominantly Muslim states in the north.

The adoption of the Islamic legal code is not new in Nigeria, but dates back to the early 1800s. Then, as now, however, it was a response to commonplace "bribery, corruption, and illegal taxes," as Karl Maier points out. ${ }^{21}$ The current crisis bloomed at the turn of the century, as local Muslim leaders in the north, "bereft of serious political programs, latched on to Sharia as an easy tool to win support from a population desperate for an end to years of frustration, corruption, and more than anything, hopelessness.... Muslims, rich and poor, educated and illiterate, flocked to the cause."22 Seven years later, Islamist politics are deeply entrenched in the north, epitomized in the extreme by a group calling itself the "Taliban," after the extremist Islamist faction deposed by the U.S. in Afghanistan after 9/11. Nigeria, the International Crisis Group

19 Ibid.

20 International Crisis Group, “Nigeria’s Faltering Federal Experiment,” Africa Report No. 119 (25 October 2006); available at www.crisisgroup.org/home/index.cfm?l=1\&id=4464.

21 Karl Maier, This House Has Fallen (London: Penguin Books, 2000), 150.

22 Ibid., 144. 
succinctly concludes, is "a cautionary tale of what happens when great potential is sabotaged by poor governance, lack of leadership and pervasive corruption.”

\section{South Africa}

The continent's most powerful state, both in terms of its strong and stable modern economy and its well-armored military, appears on no lists of failed or faltering states. South Africa, however, provides an excellent example of how key factors of state weakness - combined with a large, politically active Muslim population; historically defined cultural and trade linkages with other points in the Muslim world; and a national consciousness conditioned by centuries of oppression and decades of strugglecreate opportunities for radicalization. Put differently, the juxtaposition of relative affluence and global interconnectedness with the negative factors just mentioned make South Africa an attractive and enabling environment for terror-related activity.

In the assets column, South Africa provides the greatest degree of interconnectivity in Africa through its physical, financial, and telecommunications infrastructure. As a result, there is ready access to news and information, direct long-distance transportation, and foreign exchange. In the liabilities column, unemployment remains stubbornly at 40 percent despite a decade of internationally celebrated economic reforms reflected in one of the world's most stable emerging markets. The public education system is in crisis, and HIV/AIDS is an acute problem. Perhaps more pertinently, corruption is rife, particularly in the Department of Home Affairs, which has authority over immigration matters. South Africa's travel documentation is consequently vulnerable to easy and extensive abuse. While the country's customs intelligence is relatively strong, its border controls and port security are weak. Only one port, Durban, is equipped to scan sea containers. That capability is severely strained both by the level of traffic and by international security priorities. Durban is able to properly inspect barely 1 percent of incoming and outgoing freight, with most of the latter being destined for the United States.

South Africa, like many African states, particularly those along the eastern edge of the continent, share deep historical, cultural, and economic linkages across the Indian Ocean rim. In an age of transnational terrorism, these connections create openings for the flow of money, arms, charity, and individuals between countries like Iran, Pakistan, India, Saudi Arabia, and South Africa, Swaziland, Mozambique, and Tanzania. The growth of foreign-funded mosques, madrasas, and community centers-within both existing and new Muslim communities-attests to the strength of these ties. So, too, does the flow of laundered money and individuals.

And then there is, for want of a better term, political ambivalence. That South Africa today is ruled by a former liberation movement is relevant in the context of transnational terrorism, not because the ruling African National Congress is a terrorist organization, but rather because it was once labeled as such. The struggle against apartheid heavily informs foreign policy in South Africa today. The ANC remembers who its friends were and were not. As it aspires to be the champion of the rights of nonaligned, or Southern, states, South Africa tends to view the Western discourse of terrorism with suspicion, and to regard as friends many of those states the West has la- 
beled as "rogues.” This ambivalence is starkly embodied in legislation passed in 2006 regulating the involvement of South African citizens in foreign conflicts. The Prohibition of Mercenary Activities and Prohibition and Regulation of Certain Activities in Areas of Armed Conflict Act makes it illegal for South Africans to work for private security firms in foreign conflict zones, but allows for involvement in struggles against foreign occupation in other countries. One way to interpret that law is that, while the many South Africans employed in the contract security sector in Iraq are now suddenly engaged in illegal activity, any South African national wanting to fight with the insurgency in Iraq against Coalition troops could do so legitimately.

The combination of these factors-global interconnectedness, political ambivalence about terrorism, passport vulnerabilities, and strong cultural or family ties across the Indian Ocean-facilitates the flow of people, money, and ideas between South Africa and the Muslim world. Foreign-funded Islamic radio stations have proliferated in South Africa and engage listeners in discussions redolent with the anti-Western rhetoric of groups like $\mathrm{Al}$ Qaeda. In one indication of the potential these factors create, on 19 January 2007, two South Africans of Indian descent were placed on the UN list of international terror suspects as "facilitators and terrorist financiers" with alleged ties to Al Qaeda and the Taliban. The U.S. government provided the evidentiary documentation. Both men, Farhad Ahmed Dockrat and Junaid Ismail Dockrat, have denied the claims against them.

\section{Conclusion}

Islamism marks an attempt, whether through peaceful or violent means, to correct the ills of society wrought by secular governance through a return to religious control over all aspects of state, law, and society. It is an inherently political project. Its rapid spread across countries with Muslim majorities and those with large Muslim minorities during the past fifteen years is a symptom of the profound and widespread political alienation and economic desperation that exists across much of North Africa, the Middle East, and Asia. In the aftermath of the 11 September 2001 terrorist attacks against the United States, the West has pursued a number of strategies to cope with this trend. Most of those responses - even those meant to capture the "hearts and minds" of local Muslim communities-have been of the mechanical sort: enhancing border controls and financial sector screening capabilities, training specific counterterrorism security forces, waging wars, and so on.

Countering ideological support for terrorism, however, implies a different, deeper question: What drives radicalization? Asked in the African context, the question becomes, Why would African Muslims be lured toward Islamist ideas, and what factors would render them receptive to even violent Islamist activities? The Australian counter-insurgency expert David Kilcullen points to the answer: "It is not the people Al Qaeda might kill that is the threat. Our reaction is what can cause the damage. It's $\mathrm{Al}$ Qaeda plus our response that creates the existential danger.,23

23 Quoted in James Fallows, “Declaring Victory,” The Atlantic Monthly (September 2006), 60. 
The United States radically reshaped the entire array of global security priorities after 9/11, and led its allies off to war twice in the name of countering terrorism. In doing so, it never sufficiently debated the motivations for those attacks. The West wrongly characterized $9 / 11$ as an attack against its way of life rather than a symptomatic response to local-centric feelings of injustice, political alienation, and economic desperation. The consequences for misdiagnosing the problem in an age of globalized information and interconnectedness are dangerous and enduring. Not only has the West failed to address the root causes of Muslim antipathy, it has deepened the perception among Muslims that the war on terror is really a war against their faith and brethren in service of the pursuit of their resources.

Reversing this course requires, in the West, rethinking how interests are defined, aligned, and pursued. During the colonial and Cold War eras, engagement between Western nations and their client states was based on strategic considerations that had little to do with the needs or interests of the client states. The post-9/11 imperative is to recognize a new convergence of interests—not between developed and developing states, but between developed states and the people living in developing (or faltering) states. The critical questions become: What forms of engagement will best promote a national rather than sectarian identity? What forms of engagement build allegiance between the state and its people?

Whereas Somalia presents an open-ended challenge of trying to impose an externally constituted government on a hesitant population, the case of Somaliland underscores the importance of organic, internal processes of state building. Countering ideological support for terrorism requires identifying how to support such internal processes through external engagement. It requires dealing with the structural weaknesses that drive frustration and desperation; holding states accountable to higher standards of governance and delivery; and differentiating among Islamist groups-the majority of which eschew violence and aspire to address the socio-economic needs of their constituents. If Islamism is a political manifestation, it requires a political solution. The deepening of religious, ethnic, or sectarian identities in some African Muslim communities marks a failure by the state to cultivate a national consciousness. But such a national identity can only result from engendering allegiance through political accommodation, accountable governance, social amelioration, and more equitable distribution of the fruits of globalization that have become so visible-and so visibly denied - to most of humanity. 


\section{THE QUARTERLY JOURNAL}

\section{Bibliography}

Al Qaeda Moves to Africa. World Defense Review (2006).

Abbas, Hassan. Pakistan's Drift Into Extremism. Delhi: Pentagon Press, 2005.

Diamond, Jared. Collapse: How Societies Choose to Fail or Succeed. New York: Penguin Books, 2005.

Fabricius, Peter. "SA Troops Face 'Black Hawk Down' Perils." Sunday Independent(2007).

Fallows, James. "Declaring Victory." The Atlantic Monthly (2006).

Gerges, Fawaz. The Far Enemy: Why Jihad Went Global. Cambridge: Cambridge University Press, 2005.

Jassat, Iqbal. "Bush Goes on Africa Crusade." The Citizen (2007).

Kalpakian, Jack. "Building a Human Bomb: The Case of the 16 May 2003 Attacks in Casa-blanca." Studies in Conflict and Terrorism 28 (2005): 113-27.

Maier, Karl. This House Has Fallen . London: Penguin Books, 2000.

Mamdani, Mahmood. Good Muslim, Bad Muslim. Johannesburg: Jacana Press, 2004.

Mazzetti, Mark. "Pentagon Sees Move in Somalia as Blueprint." New York Times (2007).

Tibi, Bassam. The Challenge of Fundamentalism. Berkeley: University of California Press, 2002.

Weiss, Holger. Social Welfare in Muslim Societies in Africa. Stockholm: Nordiska Afrikainstitutet, 2002. 